\title{
MODIFICATION OF HARVARD STEP-TEST FOR ASSESSMENT OF STUDENTS' WITH HEALTH PROBLEMS FUNCTIONAL POTENTIALS
}

Kopeikina E.N., Drogomeretsky V.V., Kondakov V.L., Kovaleva M.V., Iermakov S.S. National Research University Belgorod State University

\begin{abstract}
Purpose: to substantiate, work out and experimentally prove modified test for assessment of students' with health problems functional potentials. Material: in the research students and girl students of 18-20 years' age $(\mathrm{n}=522)$ participated. According to the worked out modification of test during 30 seconds student ascended on bench $(\mathrm{h}=43 \mathrm{~cm})$ and descended from it. Then pulse was measured three times. In total the test took 4 minutes.

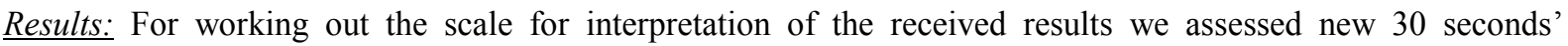
modification of Harvard step-test for validity. First, for this purpose all students fulfilled modified step-test. Then after full restoration (after 20 minutes) they fulfilled its three minutes' variant. Correlation analysis of the received results showed the presence of average correlation between two samples $(\mathrm{r}=0.64)$. Conclusions: application of this modified variant permits for pedagogues to completely assess functional potentials of students with heath problems.
\end{abstract}

Key words: students, modified, Harvard, step test, correlation analysis, functional potentials.

\section{Introduction}

At present we observe growth of quantity of students with different health problems. The conducted researches showed negative dynamic in distribution of first year students into departments for physical culture trainings $[4,20,21]$. The demand in the following is noted: dozing of physical load in physical culture training of students with cardio-vascular system's disorders [2]; varying of exercises in different modes [3]. It was found that in 2005-06 academic year 10.45\% of first year students were trained in special health group. In 2014-15 academic year the quantity of such students increased to $35.1 \%$. Next years the quantity of students with health problems still increases [8, 11, and 12]. It witnesses that in the period of study in HEE new diseases appear in students or old diseases are progressing [14, 15, and 16]. Such negative tendency is characteristic for many HEEs of Russia and Byelorussia [1, 17, and 19]. It is recommended to use means of health related physical culture by integration of information about their influence [13]. Insufficient students' physical condition and physical fitness were determined also by other scientists, when monitoring students' health [7, 17, 19]. The authors note that application of technology of students' mental and physical workability increase on the base of Pilates and step aerobic means facilitate increase of physical and mental workability, physical fitness; improvement of functional and psychoemotional state, somatic health and positively influences on progress in studying at HEE [5]. Analysis of medical records of Russian HEEs' students showed that in different regions different students' diseases prevail. Grachev A.S. found that eye diseases were $9-53 \%$ from total quantity of special health group students [9]. Kondakov V.L. et al. found that nervous and cardio-vascular systems diseases among students are detected in 9-60\%. Drogomeretskiy V.V. et al. registered disorders of muscular skeletal apparatus in $15-80 \%$ of students, digestive organs in 6-25\%, genitourinary system - in 6-23\%, respiratory system - in 5-37\% [10, 28, 29]. The same tendency was described also in other works [24].

For students with health problems organization of educational process has its own peculiarities. The absence of single state program on physical culture for special health groups students forces physical culture departments to work out own training programs. Assessment of physical culture trainings' effectiveness is one of important tasks in work with special health group students. For determination of students' health dynamic teachers apply different tests. However, a number of informative tests are not accessible for some students. It is connected with specific features of health disorders, detected in them. The conducted by us theoretical analysis and generalization of literature data on assessment of students organism's functional potentials prove the presence of problem situation. It is also proved by other researches $[6,18,30]$.

(c) Kopeikina E.N., Drogomeretsky V.V., Kondakov V.L., Kovaleva M.V., lermakov S.S., 2016 doi:10.15561/20755279.2016.0405 
The purpose of the work: is to substantiate, work out and experimentally prove modified test for assessment of students' with health problems functional potentials.

\section{Material and methods}

Participants: in the research students of main group (without health problems) participated: girls and boys of 18-20 years' age $(\mathrm{n}=522)$. All participants were familiarized with "Helsinki declaration of world health protection association" [23] and gave written consent for participation in experiments.

Organization of the research: Harvard step test is used for the following: assessment of physical potentials before sports trainings; working out of training programs; assessment of sport training programs' effectiveness; assessment of person's physical fitness by his (her) cardio-vascular system's reaction to physical load.

At present some interpretations of Harvard step test are known. All hey imply load (ascending on bench $\mathrm{h}=43 \mathrm{~cm}$ ) during 3 or 5 minutes. However, this load is excessive for most of persons with health problems. That is why teachers of physical education department of National Research University Belgorod State University worked out modified 30 seconds variant of Harvard step-test especially for students with health problems [16].

According to new modification of Harvard step-test student ascended on bench $(\mathrm{h}=43 \mathrm{~cm})$ and descended from it during 30 seconds with speed 30 steps per minute. In ascending and descending arms moved naturally like in ordinary walk. For exact dozing of frequency of ascends and descends we used metronome. Frequency of metronome was adjusted for 120 beats per minute (every movement corresponded to one metronome beat). After fulfillment of step-test student had rest in sitting position. The his pulse was measured three times (1.5 minutes since beginning of the test) during 30 seconds $\left(\mathrm{P}_{1}\right)$, after 2 minutes of rest ( 2.5 minutes since beginning of the test) during 30 secondsв $\left(\mathrm{P}_{2}\right)$, after 3 minutes of rest ( 3 minutes since beginning of the test) during 30 seconds $\left(\mathrm{P}_{3}\right)$. In total test took 4 minutes.

Coefficient was calculated by the following formula:

$$
\mathrm{K}=(\mathrm{t} \cdot 100) /\left(\mathrm{P}_{1}+\mathrm{P}_{2}+\mathrm{P}_{3}\right) .
$$

For working out interpretation scale of the received results we assessed for validity new 30 seconds' modification of Harvard step-test. For this purpose 522 absolutely healthy students fulfilled first modified steptest. Then, after complete restoration (in 20 minutes) they fulfilled 3-minutes' variant of test.

Statistical analysis: we conducted correlation analysis of the received results. The analysis showed the presence of average correlations between two samples ( $\mathrm{r}=0.64)$. Program SPSS 22 was used.

\section{Results of the research}

For working out interpretation scale of the received results of 30 seconds' Harvard step-test modification for students with weakened health we carried out correlation analysis of the received data. The data were analyzed for the presence of statistical correlation in the given sample. In fig. 1 the received results are presented visually.

Analysis of the obtained data permits to notice regularity in distribution of heart beats rate values in both variants of Harvard step-test.

Besides, we formed correlation field (see fig. 2). Analysis of this field permitted to find perfect correlation of the studied data. We determined that higher values of one property are corresponded to by higher values of other property. In the same way lower values of one property are corresponded to by lower values of other. Thus we can say about average correlation between two samples $(\mathrm{r}=0.64)$.

The received data permitted to work out the following interpretation scale of Harvard step-test 30 seconds' modification results for persons with weakened health:

"Excellent" - 26 conv. un. and more;

"Average" - 20-22 conv. un.;

"Weak" - 17-19 conv. un.;

"Bad" - 16 conv. un. and less.

And finally, it should be noted that the conducted research of students' functional potentials permitted to prove reliability of the worked out modification of 30 seconds' Harvard step-test. The accumulated up to present 
time experimental material on this problem witnesses that with the help of 30 seconds' modification of Harvard step-test specialists can completely assess functional potentials of students with health problems.

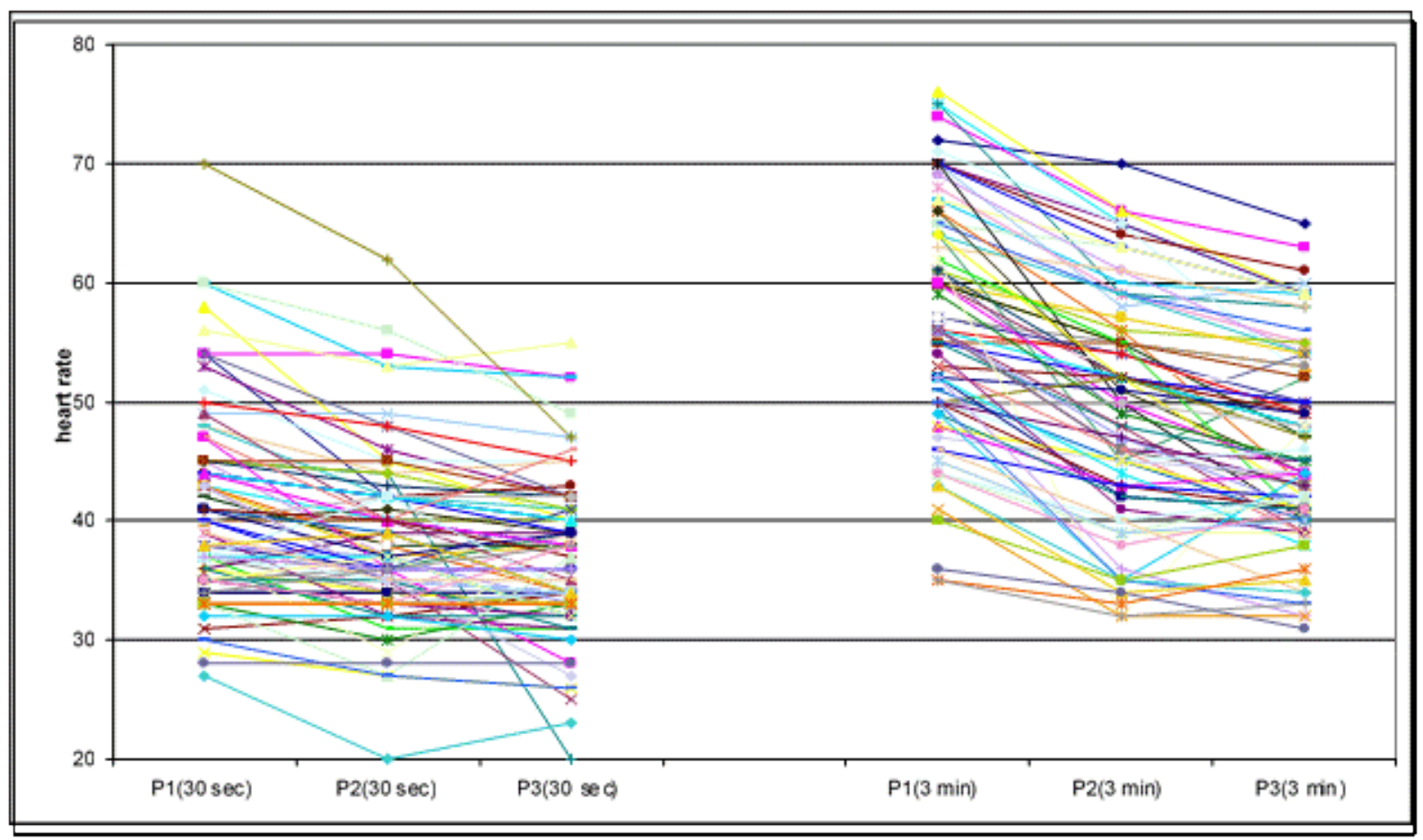

Fig.1. Results of heart beats rate (HBR) measurements with fulfillment of 3 minutes' and 30 seconds' variant of Harvard step-test.

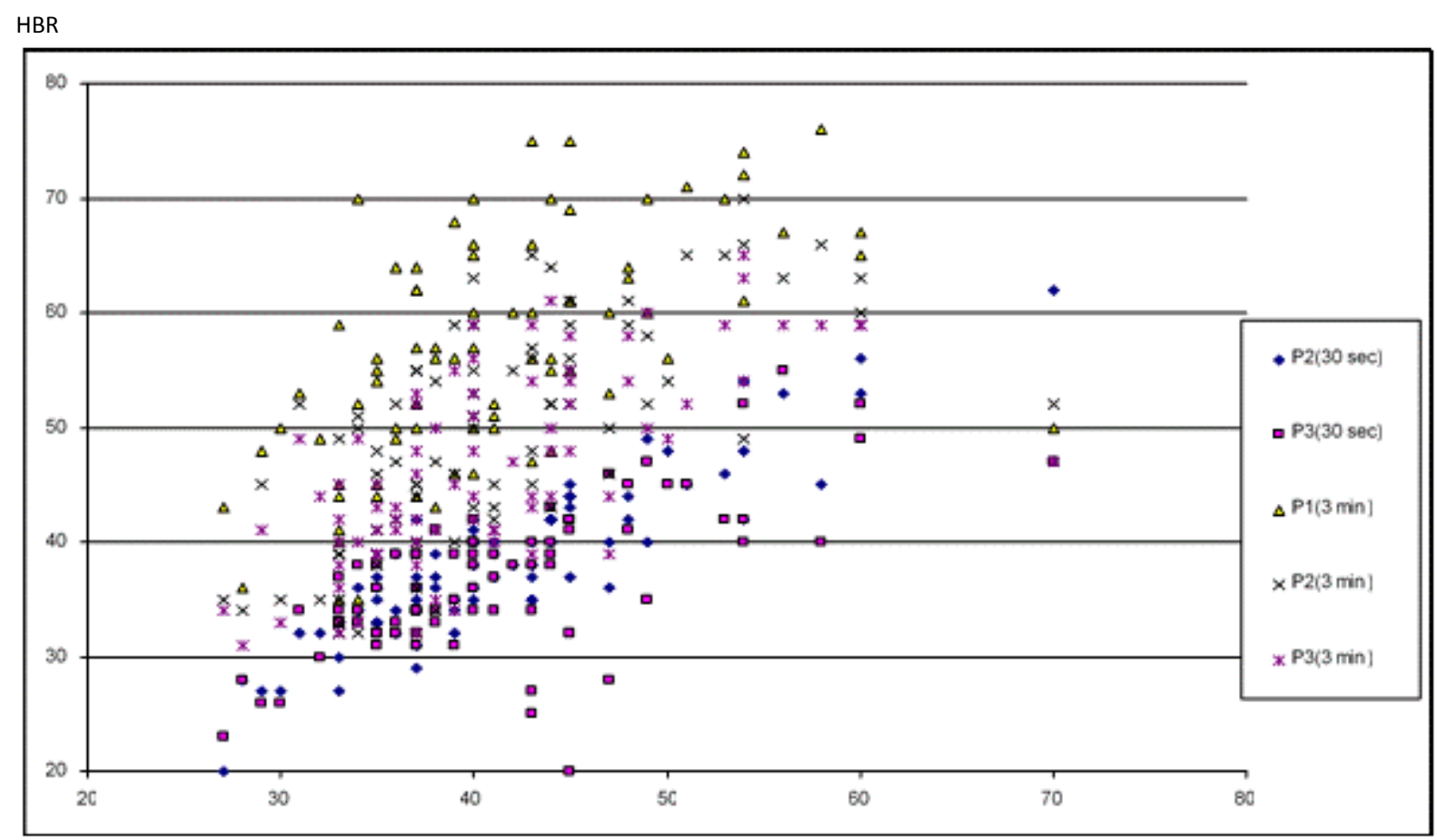

Fig.2. Correlation field of heart beats rate (HBR) measurement results' distribution with fulfillment of 3 minutes' and 30 seconds' variant of Harvard step-test. 


\section{Discussion}

The carried out monitoring of students' health showed tendency to its worsening during studying at HEE. Specialists in physical culture and sports point at existence of substantial restrictions in physical exercises' fulfillment by students with different health problems [27]. However, there is a demand in reliable functional and control tests, which could be applied for assessment of functional potentials of students with health problems. Results of prof. Zaporozhanov's works prove correctness of such approach. The author showed purposefulness of perfection of dexterity control for substantiation of kinesthesia quantitative and qualitative assessment in specific conditions of physical education [31]. Besides, the need in the following is noted:

- To base on objective, metric information, received in researches with wide contingent of participants, who demonstrate good concentration of attention and high reliability of results in series of repeated measurements [33];

- Substantiation of more reliable informative indicators and purposefulness of their calculation for control over sportsmen's complex fitness [34];

- Purposefulness of usage of only previously substantiated and reliable results in statistical operations [32].

The conducted by us analysis of scientific works did not show suitable functional tests, which could permit to assess functional potentials of students with health problems. The existing modifications of Harvard steptest are suitable for healthy people of different age and sex [22, 24, and 27]. Application of the worked out by us modified 30 seconds' Harvard step-test permits for specialists to completely assess functional potentials of students, for whom earlier usage of tests had counter-indications because of these students' health. Study of functional potentials of students with health problems permitted for us to prove the reliability of the worked out 30 seconds' Harvard step-test. Our research permits to assume that for other age groups with health problems the worked out by us step-test modification can also be applied.

\section{Conclusions}

The worked out by us modified 30 seconds' variant of Harvard step-test is now being widely used by physical education departments of Russian HEEs. Usage of adapted variants of this test permits for pedagogues to completely assess functional potentials of students with different health problems.

\section{Conflict of interests}

The authors declare that there is no conflict of interests.

\section{References}

1. Afanas'eva IV, Verigo LN. Analiz fizicheskogo razvitiia i sostoianiia studentov Omskogo gosudarstvennogo instituta servisa [Analysis of physical condition and state of students of Omsk state university of service]. Nauchno-metodicheskoe obespechenie fizicheskogo vospitaniia, sportivnoj trenirovki i ozdorovitel'noj fizicheskoj kul'tury, 2004;7(1): 120-132. (in Russian)

2. Balysheva NV. Ukreplenie zdorov'ia studentok, imeiushchikh narusheniia serdechno-sosudistoj sistemy, sredstvami dozirovannoj ozdorovitel'noj khod'by i bega. Kand. Diss. [Health improvement of girl students, who have cardio vascular system disorders by means of dozed health related walks and run. Cand. Diss.], Sankt Petersburg; 2010. (in Russian)

3. Bogoeva MD. Postroenie processa fizicheskogo vospitaniia studentov special'noj medicinskoj gruppy $s$ ogranichennymi vozmozhnostiami serdechno-sosudistoj sistemy. Kand. Diss. [Construction of physical education process for special health group students with restricted potentials of cardio-vascular system. Cand. Diss.], Sankt Petersburg; 2011. (in Russian)

4. Bogoeva MD, Rumba OG, Gorelov AA. Postroenie processa fizicheskogo vospitaniia studentov special'noj medicinskoj gruppy s ogranichennymi vozmozhnostiami serdechno-sosudistoj sistemy [Construction of physical education process for special health group students with restricted potentials of cardio-vascular system], Belgorod: CPI "Politerra"; 2011. (in Russian)

5. Bocharova VI. Integraciia sredstv pilatesa i step-aerobiki dlia obespecheniia rabotosposobnosti studentov. Kand. Diss. [Integration of Pilates and step-aerobic means for ensuring students' workability. Cand. Diss.], Sankt Petersburg; 2013. (in Russian) 
6. Butenko MV. Formirovanie kul'tury ZOZh lichnosti studenta v processe zaniatij atleticheskoj gimnastikoj. Kand. Diss. [Formation of student's personal healthy life style culture in the process of athletic gymnastic training. Cand. Diss.], Omsk: SibGUFK; 2004. (in Russian)

7. Goginava SE. Sochetanie sredstv aerobnoj i anaerobnoj napravlennosti na zaniatiiakh po fizicheskoj kul'ture $v$ vuze. Kand. Diss. [Combining of step-aerobic and anaerobic means at physical culture classes in HEE. Cand. Diss.], Tambov: TSU; 2014. (in Russian)

8. Gorobij AIu, Kondakov VL, Tret'iakov AA. Dvigatel'naia aktivnost' v zhizni studentov gumanitarnogo vuza [Motor functioning in life of Humanitarian HEE students]. Kul'tura fizicheskaia i zdorov'e, 2013;2 (44):1820. (in Russian)

9. Grachev AS. Tekhnologiia uluchsheniia funkcionirovaniia zritel'nogo analizatora slabovidiashchikh studentov sredstvami sportivnykh i podvizhnykh igr. Kand. Diss. [Technology of students with weak eyesight visual analyzer's functioning improvement by means of outdoor games. Cand. Diss.], Sankt Petersburg; 2013. (in Russian)

10. Drogomereckij VV. Korrekciia narushenij sustavno-sviazochnogo apparata studentov special'nykh medicinskikh grupp sredstvami ozdorovitel'nogo plavaniia. Kand. Diss. [Correction of joint-ligament apparatus disorders in sudent of special health groups by means of health related swimming. Cand. Diss.], Sankt Petersburg; 2012. (in Russian)

11. Kovaleva MV. Metodika primeneniia podvizhnykh i elementov sportivnykh igr na zaniatiiakh so studentami special'nykh medicinskikh grupp s ogranichennymi vozmozhnostiami serdechno-sosudistoj sistemy. Kand. Diss. [Methodic of outdoor games' elements' application at trainings of special health group students with weak cardio-vascular system. Cand. Diss.], Shuya; 2012. (in Russian)

12. Kovaleva MV, Rumba OG. Primenenie podvizhnykh i elementov sportivnykh igr na zaniatiiakh so studentami s ogranichennymi vozmozhnostiami zdorov'ia serdechno-sosudistoj sistemy [Application of outdoor games' elements at trainings of special health group students with weak cardio-vascular system], Belgorod: Politerra; 2012. (in Russian)

13. Kondakov VL. Sistemnye mekhanizmy konstruirovaniia fizkul'turno-ozdorovitel'nykh tekhnologij $v$ obrazovatel'nom prostranstve sovremennogo vuza. Dokt. Diss. [Systemic mechanisms of health related physical culture technologies' construction in educational space of modern HEE. Dokt. Diss.], Sankt Petersburg; 2013. (in Russian)

14. Kondakov VL, Kopeikina EN, Balysheva NV. Health and fitness technology to prevent respiratory disorders. Theory and practice of physical culture, 2016;1:34-36.

15. Kopeikina EN, Bogoeva MD. Dykhatel'nye uprazhneniia kak sredstvo povysheniia somaticheskogo zdorov'ia studentov [Breathing exercises as mean of students' somatic health improvement]. Ekonomicheskie $i$ gumanitarnye issledovaniia regionov, 2011;6:17-23. (in Russian)

16. Kopeikina EN. Postroenie processa fizicheskogo vospitaniia studentok s narusheniiami $v$ sostoianii dykhatel'noj sistemy. Kand. Diss. [Construction of physical education process for girl students with respiratory system disorders. Cand. Diss.], Belgorod; 2010. (in Russian)

17. Markevich OP, Medvedev VA. Morfofunkcional'nye pokazateli studentok pervogo kursa, otnesennykh k special'noj medicinskoj gruppe [Morphological functional indicators of 1st year girl students, related to special health group]. 7 Mezhdunarodnaia nauchnaia konferenciia "Nauchnoe obosnovanie fizicheskogo vospitaniia, sportivnoj trenirovki i podgotovki kadrov po fizicheskoj kul'ture i sportu”, Minsk, 6-8 aprelia 2004 [7th International scientific conference "Scientific substantiation of physical education, sport training and training of personnel for physical culture and sports", Minsk, April 6th - 8th, 2004]. Minsk; 2004. P. 282-283. (in Russian)

18. Pustozerov AI, Gostev AG. Ozdorovitel'naia fizicheskaia kul'tura [Health related physical culture], Chelyabinsk: South Ural State University; 2008. (in Russian)

19. Retiunskikh LF, Kashkarov VA, Chesnokova EA. Monitoring zdorov'ia kak forma kontrolia fizicheskogo razvitiia studentov [Health monitoring as form of control over students' physical condition]. IV Mezhdunarodnaia nauchno-prakticheskaia konferenciia "Fizicheskaia kul'tura i zdorov'e studentov vuzov", 
31 marta 2008, SPb. [4th International scientific-practical conference "Physical culture and health of HEE students", 31st of March, 2008, SPb.], Sankt Petersburg; 2008. (in Russian)

20. Rumba OG. Sistemnye mekhanizmy regulirovaniia dvigatel'noj aktivnosti studentov special'nykh medicinskikh grupp [Systemic mechanisms of motor functioning regulation in special health group students], Belgorod: Publishing House "Lit caravans"; 2011. (in Russian)

21. Tret'iakov AA. Tekhnologiia povysheniia ustojchivosti studentov $k$ nervno-emocional'nomu napriazheniiu v processe obrazovatel'noj deiatel'nosti s ispol'zovaniem sredstv fizicheskoj kul'tury. Kand. Diss. [Technology of strengthening of students' resistance to nervous-emotional tension with the help of physical culture means in the process of educational activity. Cand. Diss.], Belgorod; 2011. (in Russian)

22. Tupikina AA, Plotnikova IV, Kovalev IA, Svincova LI, Dzhaffarova OIu, Ianulevich OS, Krivoshchekov EV. Opredelenie tolerantnosti $\mathrm{k}$ fizicheskoj nagruzke u zdorovykh detej s ispol'zovaniem modificirovannogo Garvardskogo step-testa [Determination of healthy children's tolerance to physical load with the help of modified Harvard step-test]. Sibirskij medicinskij zhurnal, 2015;30(4):36-39. (in Russian)

23. WMA Declaration of Helsinki - Ethical Principles for Medical Research Involving Human Subjects [Online] Available from: http://www.ub.edu/recerca/Bioetica/doc/Declaracio_Helsinki_2013.pdf [Accessed 15th April 2016].

24. Bruce R. Methods of exercise testing. Am. J. Cardiol. 974;33:715-720.

25. Drogomeretsky VV, Kondakov VL, Gorelov AA. Application of improving swimming to the correction of joint and ligament students. Physical Education of Students, 2013;5:46-54. doi:10.6084/m9.figshare.771046

26. Fernando RJ, Ravichandran K, Vaz M. Aerobic fitness, heart rate recovery and heart rate recovery time in indian school children. Indian Journal of Physiology and Pharmacology, 2015;59(4):407-413.

27. Francis KT. A new singlestage step test for the clinical assessment of maximal oxygen consumption. Pbys. Ther. 1990;70:734-738.

28. Kondakov VL, Kopeikina EN, Usatov AN. On purposefulness of application of physical culture health related technology for prophylaxis of students' respiratory system disorders. Physical education of students, 2016;2:4-12. doi:10.15561/20755279.2016.0201

29. Kondakov VL, Voloshina LN, Balysheva NV, Kopeikina EN, Skrug DA. Correction of the state of cardiovascular system of undergraduates by means of dosed constitutional walking and jogging. Research Journal of Medical Sciences, 2015;9(3):95-98.

30. Skurikhina NV, Kudryavtsev MD, Kuzmin VA, Iermakov SS. Fitness yoga as modern technology of special health groups' girl students' psychophysical condition and psycho-social health strengthening. Physical education of students, 2016;2:24-31. doi:10.15561/20755279.2016.0204

31. Zaporozhanov VA. About reliable indicator of proprioception in agility control. Pedagogics, psychology, medical-biological problems of physical training and sports, 2013;4:21-25. doi:10.6084/m9.figshare.693023

32. Zaporozhanov VA, Boraczyński T. On the transfer of skills skill in different conditions of motor activity. Pedagogics, psychology, medical-biological problems of physical training and sports, 2013;9:2528. doi:10.6084/m9.figshare. 749693

33. Zaporozhanov VA, Boraczynski Tomasz. Discussion on the concepts of "coordination" and "agility" in terms of physical education. Pedagogics, psychology, medical-biological problems of physical training and sports, 2015;3:15-19. doi:10.15561/18189172.2015.0303

34. Zaporozhanov VA, Kochanowicz K, Kochanowicz A. Improvement of comprehensive assessment of specially trained childhood and adolescence gymnasts. Pedagogics, psychology, medical-biological problems of physical training and sports, 2014;10:3-7. doi:10.5281/zenodo.10482 


\section{Information about the authors:}

Kopeikina E.N.; http://orcid.org/0000-0002-6027-3495; kopeikina@bsu.edu.ru; National Research University Belgorod State University; Pobeda 85, Belgorod, 308015, Russia.

Drogomeretsky V.V.; http://orcid.org/0000-0002-4749-2853; drogomeretskiy@bsu.edu.ru; Belgorod State National Research University; Pobeda Str., 85, Belgorod, 308015, Russia.

Kondakov V.L.; http://orcid.org/0000-0002-8094-0144; kondakov@bsu.edu.ru; National Research University Belgorod State University; Pobeda 85, Belgorod, 308015, Russia.

Kovaleva M.V.; http://orcid.org/0000-0002-4764-0772; kovaleva_m@bsu.edu.ru; Belgorod State Technological University named after V.G.Shoukhov; Kostyukov str., 46, Belgorod, 308012, Russia.

lermakov S.S.; http://orcid.org/0000-0002-5039-4517; sportart@gmail.com; National Research University Belgorod State University; Pobeda 85, Belgorod, 308015, Russia.

Cite this article as: Kopeikina E.N., Drogomeretsky V.V., Kondakov V.L., Kovaleva M.V. Iermakov S.S. Modification of Harvard step-test for assessment of students' with health problems functional potentials. Physical education of students, 2016;44:4-50. doi:10.15561/20755279.2016.0405

The electronic version of this article is the complete one and can be found online at: http://www.sportpedu.org.ua/html/arhive-e.html

This is an Open Access article distributed under the terms of the Creative Commons Attribution License, which permits unrestricted use, distribution, and reproduction in any medium, provided the original work is properly cited (http://creativecommons.org/licenses/by/4.0/deed.en).

Received: 05.08.2016

Accepted: 19.08.2016; Published: 28.08.2016 